\title{
Sand Dunes in Qassim Region: Geomorphological Characteristics and Economic value "An Empirical Study"
}

\section{By}

Hamdeno Al-Awady and Ahmed Al-Dughairi

Professor, Geography Department, Qassim University and Alexandria University

Associate Professor, Geography Department, Qassim University 


\section{ABSTRACT:}

OSL dating technique has shown different periods of sand accumulation in the Qassim region. The lithified basis of dune fields at depth more than $50 \mathrm{~m}$ under the general level were accumulated and formed during Pleistocene age (99.5 Ka). Consequently, two different dune patterns were formed, the lower or older dunes at the early of Holocene $(9.8 \mathrm{Ka})$, then the upper or recent ones were formed from $3.5 \mathrm{Ka}$ until only 200 years ago. Recent pattern is active and mainly formed from barchans and transverse types, but the older one is inactive and consists essentially of dome-shaped dunes. Between them, there is a grassy surface at varying elevations above sea level. This surface separates between to two different distinct sand faces as well as two different periods of dune formation. The main geomorphological features of these dunes are discussed on the basis of dune type, origin, wind direction and velocities, wind ripples, internal structure and dune vegetation.

An attempt was made to differentiate between the two patterns of sand dunes as well as the sediments of Wadi ar Rumah's floodplain. The differentiation depends upon grain size distribution curves, statistical parameters, geochemical characteristics and OSL dating techniques. The older dune sands are finer, more sorted, positive skewed and have slightly lower kurtosis values than the recent ones and also the Wadi ar Rumah floodplain. On the other hand, the study of geochemical characteristics indicates that the older dunes and the floodplain of Wadi ar Rumah are more alkaline than the recent dunes. While the EC and TDS tend to increase in the recent dunes than the older dunes and Wadi ar Rumah floodplain. Carbonate, bicarbonate and chloride in general occur in narrow range as a result of weathering. While the concentration of micronutrient metals $(\mathrm{Fe}, \mathrm{Mg}, \mathrm{Zn}$ and $\mathrm{Cu}$ ) decrease significantly with the decreasing in finer fractions.

Key words: Nafud, sand dunes, grain size, geochemical, wind ripples, internal structure, dune vegetation, Qassim Region and Saudi Arabia.

INTRODUCTION: There are several types of surface sediments in the Qassim region, with different characteristics, but the deposits of sand dunes are absolutely common, they are the most common type and abundance between the types of surface's sediments, this situation is not much different than the rest of Saudi Arabia. Whereas, the dune sands are formed about $30 \%$ of the Arabian Shelf area. These sediments are concentrated in four main sandy Seas are: Nafud Al-Kapeer in the north, Dahnaa and Gaforah in the east, and Al-Ruba Al khali in the south. Moreover, there are smaller sand accumulation at the Arabian Shelf, they are formed sand fields in the Qassim region, such as Nafud Al-Thwairat, Nafud Al-Tarfyya, Nafud Ash Shuqayyiqah, Nafud Al-Ghamis, Nafud Al-Aurayyq, Nafud Al- Maysariyah and others. The area of Qassim region is estimated in about $127350 \mathrm{kms}$, sand dunes cover about 17829 $\mathrm{kms}$ from this area, which represents about $14 \%$ of the total area. 
Several studies were unanimous that the sand accumulation and sand dunes in the Qassim region and neighboring areas were formed during dry periods (inter-pluvial) during the Pleistocene era, most likely in the second half of Pleistocene. The sand dunes in Qassim Region are successive generations of accumulation sand and sand dunes. Oldest dunes form their bases while, recent ones form dune peaks. This research concerns with to study the sand dunes in the Qassim region in general, as a result the significant of these dunes and their impact on urbanization and economic activities, and their effect on development plans at the present time and in the future. Through the study of grain-size properties, mineralogical and chemical of dune sands, as well as the study of the internal structure of these dunes.

PROBLEM AND SIGNIFICANCE: Sand dunes (Nafud) are spread in the Qassim region, and are covering large areas. Although some of them fixed and stable, others moving and poses a threat to urbanization and farms. Moreover, the dune materials are considered a source of dust storms that attack the Qassim region and neighboring areas. Therefore, the research strategy is to study the geomorphological characteristics of these dunes; to determine the seriousness of the moving ones under the effect of the wind, and to develop an appropriate mechanism to install those dunes and ward off their dangers, and also to study the economic value of these dunes and discuss the ways to take advantage of them, according to the applied scientific approaches that are used universally in this field of applied studies.

In the Qassim region, the sand dunes determine forms and patterns of ancient and modern urbanization, they are also shaped the economic situation especially the agriculture, industry and also the transport roads, etc. According them, the development plans are carrying out at the present and in the future. Therefore, the importance of research is determined in the consolidation and the establishment of the concept of coexistence with the natural phenomena due to academic and applied perspective aims to avoid the dangers of these dunes, and discuss the ways to utilize them, especially the sand dunes in the Qassim region are not studied geomorphologically and economically before, although they are the most important physical phenomena prevailing in the Qassim region. 
OBJECTIVES: The study seeks to achieve a number of objectives are:

1- Stand on the sand supply of the sand dunes, in an attempt to estimate their sizes at present and in the future.

2 - Determine the dunes, which move and migrate under the influence of wind action, because they are more dangerous on the urbanization and economic activities, through the study of their geomorphological characteristics.

3 - Discuss ways to take advantage of those dunes economically, due to carrying out grain-size, OSL dating and geochemical analysis of collected samples.

4 - The study of the internal structure of these dunes to know the factors and processes of their origin and evolution. Whereas, the present is the key to the past and the future.

5 - Carrying out detailed map for the distribution of sand dunes in the Qassim region, to helps the planner in the development plans at the present time and the future.

METHODOLOGY: Due to the nature of the present study, and in order to achieve the objectives, systematic and analytical approaches were used, as well as a sophisticated technique. Moreover, this study was depended essentially on the field study to carry the following steps:

1- Collect sample series from order and recent sand dunes to experimental analysis (grain size, OSL dating, and Geochemical analysis).

2 -Measurements of areas and dimensions of certain patterns of sand dunes.

3 -Complete the deficiencies in the reference data, and detailed maps. 4 - Photographic documentation of the most significant dune types and their landforms.

\section{WIND REGIME (DIRECTION AND VELOCITY)}

Wind data for period of thirty-four years (1980- 2014) were obtained from Buraydah Airport station. These are presented in Table 1 and diagram (Fig. 1). These data indicate that the prevailing wind comes essentially from N, ENE, E and NE, although winds from all directions are represented. Hence, the presence of a prevailing wind, effective in sand transport has been clearly established for the recent sand dunes of the study area. 
(Table 1): Directions and frequency ratios of the wind at Buraydah Airport Station during the period from 1980 to 2014

$\begin{array}{cccccc}\text { Direction } & \text { Frequency } & \% & \text { Direction } & \text { Frequency } & \% \\ \text { N } & 128 & 34.4 & \text { S } & 19 & 5.1 \\ \text { NNE } & 45 & 12 & \text { SSW } & 8 & 2.15 \\ \text { NE } & 37 & 9.9 & \text { SW } & 13 & 3.5 \\ \text { ENE } & 43 & 11.56 & \text { WSW } & 4 & 1 \\ \text { E } & 41 & 11 & \text { W } & 1 & 0.26 \\ \text { ESE } & 3 & 0.8 & \text { WNW } & 1 & 0.26 \\ \text { SE } & 3 & 0.8 & \text { NW } & 1 & 0.26 \\ \text { SSE } & 6 & 1.6 & \text { NNW } & 19 & 5.1\end{array}$

(Table 2): The Monthly averages of wind velocity $(\mathrm{km} /$ hour) at Buraydah Airport station during the period from 1980 to 2014

Month Jan. Feb. Mar. Apr. May June July Aug. Sep. Oct. Nov. Dec. $\begin{array}{lllllllllllll}\text { V.km/h } & 9.6 & 11.7 & 12.4 & 12.8 & 12.8 & 11.3 & 10.5 & 9.8 & 9.1 & 9.1 & 10.2 & 9.6\end{array}$

Data of wind velocity (Table 2) and wind rose diagram (Fig. 1-A) indicate that the wind velocity ranges from 9.1 To $12.8 \mathrm{~km} /$ hour, with an annual average of $10.7 \mathrm{~km} /$ hour. The relative strong winds occur during spring season, especially during April and May, $13.8 \mathrm{~km} /$ hour for each month.
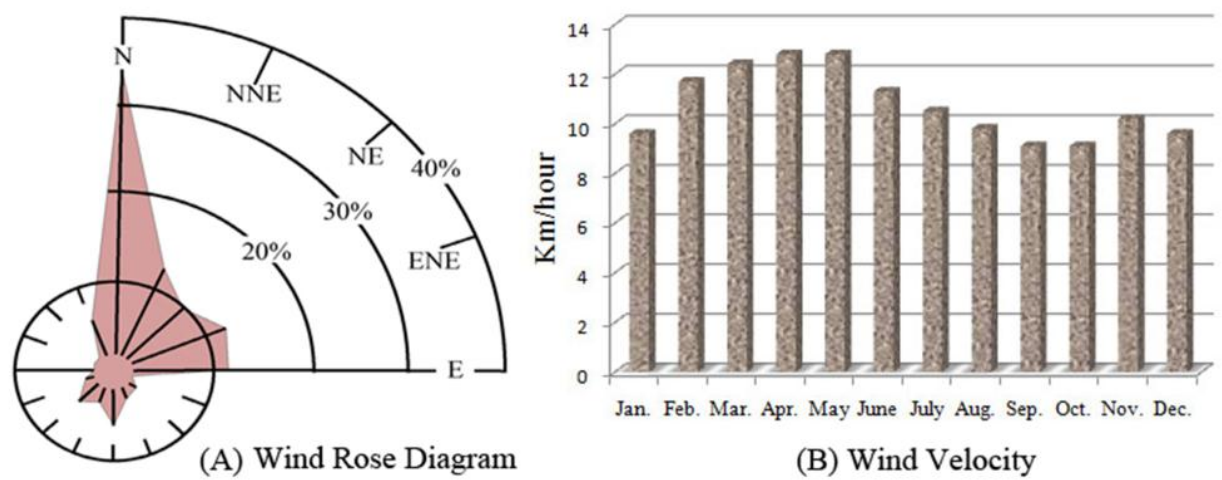

Figure 1: Wind Direction and Velocity at Buraydah Airport (1980-2014)

of self-organization in Aeolian systems (Anderson, 1990). They are the initial response of sand surfaces to sand transport by the wind, and form because flat sand surfaces over which transport by saltation and reptation takes place are dynamically unstable (Bagnold, 1941). The formation and 
movement of wind ripples are therefore closely linked to the processes of saltation and reptation.

On the dunes under investigation, Wind ripples abound on surfaces of blown sand. These ripples are laterally extensive straight, and parallel crested to slightly sinuous crested (Fig.2). Their gentler slope sides lying at the windward direction (N, NE and NNE), while their lee-ward sides (S, SW and SSW) are steeper. The wavelength is seldom less than $12 \mathrm{~cm}$ (Fig.2-A and C), and rarely greater than $50 \mathrm{~cm}$ (Fig.2-B). The ripples amplitudes range between $0.5-2.5 \mathrm{~cm}$ with an average of $1.5 \mathrm{~cm}$. The ratio between ripple length and height is given by ripple index, which can be used to compare ripples in different environments (Parson and Abrahams, 2009). Accordingly, the ripple index ranges between 25-28. It is well known that wind ripples have greater ripple index (20-90) than asymmetric water ripples (4-10). As field data were indicated that the coarsest sand grains are commonly at the ripple crests. On the other hand, the finest ones tend to concentrate in the ripple troughs (Fig.2). This fact is in agreement with R.A. Bagnold (1971), R.S. Anderson (1990) and J.W. Boulton (1997).
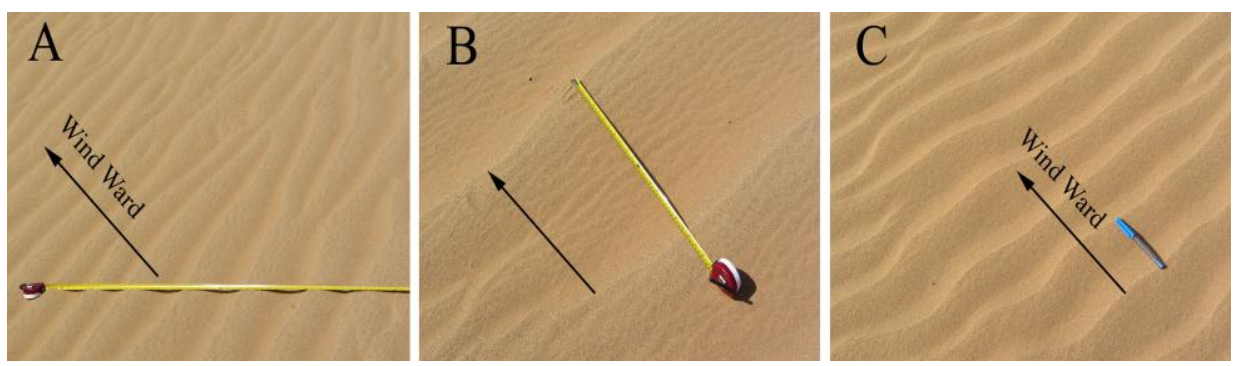

Figure 2: Varying types of wind sand ripples in Qassim Region

areas with less than $100 \mathrm{~mm}$ of annual average rainfall. Rainfall is a limiting factor only where the annual average is very low $(<50 \mathrm{~mm})$. Vegetation plays an important role in the stabilization of the dunes under investigation and also promotes its growth by providing a trap for windblown sand.

In the study area, some monsoonal grasses such as Alliums pp., Planlago albicans and Neurada procumbens are only observed during the winter season. Beside grasses, on the other hand, it is observed that Haloxylon persicum and Hammada elegans are intensive covering both dune types. The clumps of Hammda elegans are covering the old sand dunes, but the clumps of Haloxylon persicum tend to concentrate 
especially on the recent dune sides. On the other hand, the clumps of Acacia raddiana and Acacia tortilis are observed. Isolated clumps of both Haloxylon persicum and Hammada elegans act as sand traps and thus lead to the formation of nebkhas (coppice dunes). Such plants play an important role in binding together the sand by their complex root system and thus help to protect the dune sands from the erosive action of wind. If the plants are weakened for any reason, for example, by trampling of cars and people walking over the dunes, as a result, sands will be exposed to wind action and the loose grains will blow away. Thus, the form of dunes will have altered and appears as dome-shaped. Such phenomenon has been observed in some used and inhabited area.

GEOMORPHOLOGICAL CHARACTERISTICS: It is important to note, that the general landscape in Qassim region consists chiefly of broad peneplains covered by thin surficial mantles, and scattered isolated hills whose summits are 50 to $500 \mathrm{~m}$ higher than the surrounding plains. The general altitude of the peneplains is between $570-950 \mathrm{~m}$ above sea level, they have more leveling in the western portions more than the eastern ones.

Vertically (from top to bottom) dune fields in Qassim region are generally characterized by two dune patterns, are different in extension, form and age. The lower pattern is older, inactive, variably vegetated and light-gray in color due to a surface lag deposits of quartz-feldspar sand. Most dunes of this pattern consist of dome-shaped dunes. The upper pattern is recent, active, less vegetated and red to red-orange in color due to the higher proportion of unstable iron-bearing minerals in the fine sand size class. Most dunes of this pattern consist of barchans and barchanoid dunes especially on the flanks of the inactive dunes.

The two dune patterns represent two distinct periods of dune formations. Between them there is a continuous grassy surface, this surface is at varying elevation above sea level. At the southern banks of wadi ar Rumah channel and many inland hollows of al Maysariyah field dune, very clear sections are observed in contact with the older, lower surface and the younger, higher dunes. However, the grassy surface separates two different faces of dune. The lower dunes may be accumulated prior to 33000 years B.P. as some studies (Whitney, 1983; Cole, 1988) indicated, whereas the upper ones are recent.

SAMPLES AND PROCEDURES: For studying the grain size characteristics and grain size relationship between the recent and the older sand dunes and also the old floodplain of Wadi al Rumah that represent 
the surface of sand dunes accumulation, three series of samples were collected; one from Nafud al Maysariyah recent dunes (3 samples), one from the older dunes of Nafud al Maysariyah (3 samples), Nafud Qwarh (2 samples), Nafud Uyun Al Jiwa (2 samples) and Nafud Buridah (5 samples), other series (2 samples) were collected from Wadi ar Rumah's floodplain.
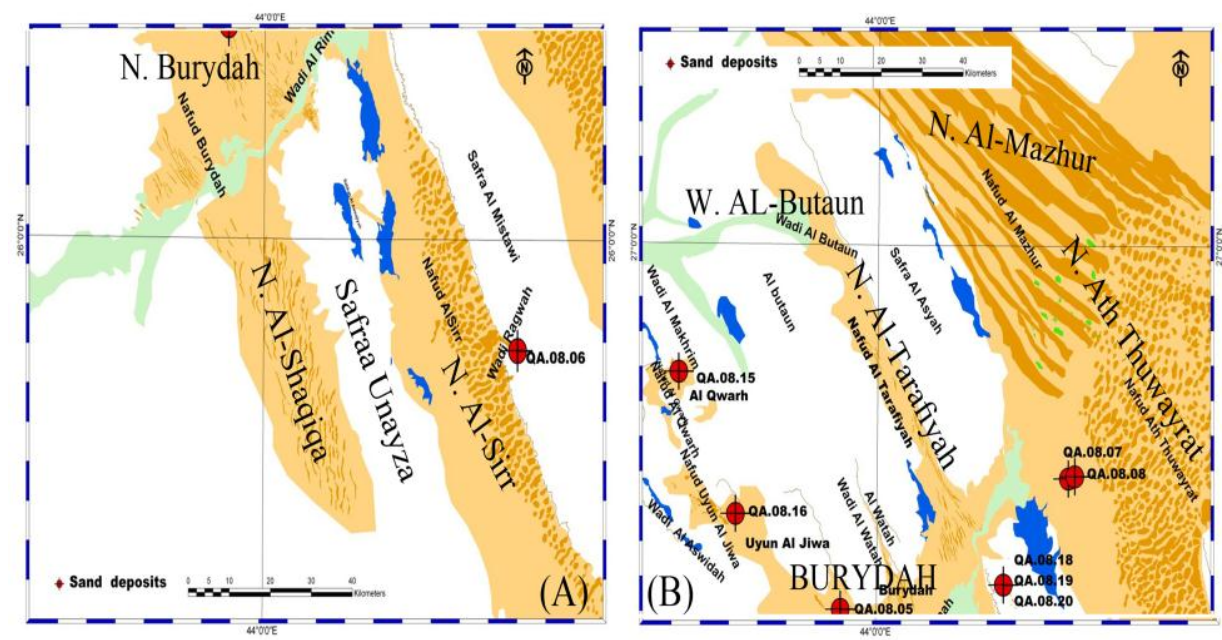

Figure 3: Sand dune fields distribution in southern (A) and northeastern (B) sectors of the study area as well as collected sample sites.

method using a Ro-Tap shaker. About 200 gm split of each sample wa ̌ sieved for 20 minutes. It is planned to use the half phi interval in between 3- 4 phi set of sieves to give more accurate curves and statistical parameters. Then the cumulative percentages were plotted on probability paper and graphical method was used. The grain size statistical parameters were calculated using the equations of Folk and Ward (1957).

To obtain accurate dating, Optically Stimulated Luminescence (OSL) analysis was carried out for older or lower sand dunes of Nafud Qwarh (2 samples), Nafud Uyun Al Jiwa (2 samples), and Nafud Buridah (4 samples). Geochemical analysis was also carried out for all collected samples of al Maysariyah sand field and Wadi ar Rumah's floodplain.

\section{RESULTS ABD DISCUSSION}




\section{1- Nafud Al Qwarh QA.08.15}

Nafud Al Qwarh is located on the western outskirts of the town of Al Qwarh (26 $\left.46^{\prime} 12^{\prime \prime} \mathrm{N}-43^{\circ} 27^{\prime} 97^{\prime \prime} \mathrm{E}\right)$. The Nafud is flanked by Al Qwarh escarpment in the north-west and extends for $10 \mathrm{~km}$ from Wadi Al Makhrim to Al Qwarh village (Fig.3). Section QA.05.15 is an Aeolian deposit that has been exposed as a transverse section through a linear dune. It comprises $10 \mathrm{~m}$ of flat low angle curved beds (Fig.4) that can be distinguished on the basis of small variations in particles size analysis (Fig.4).
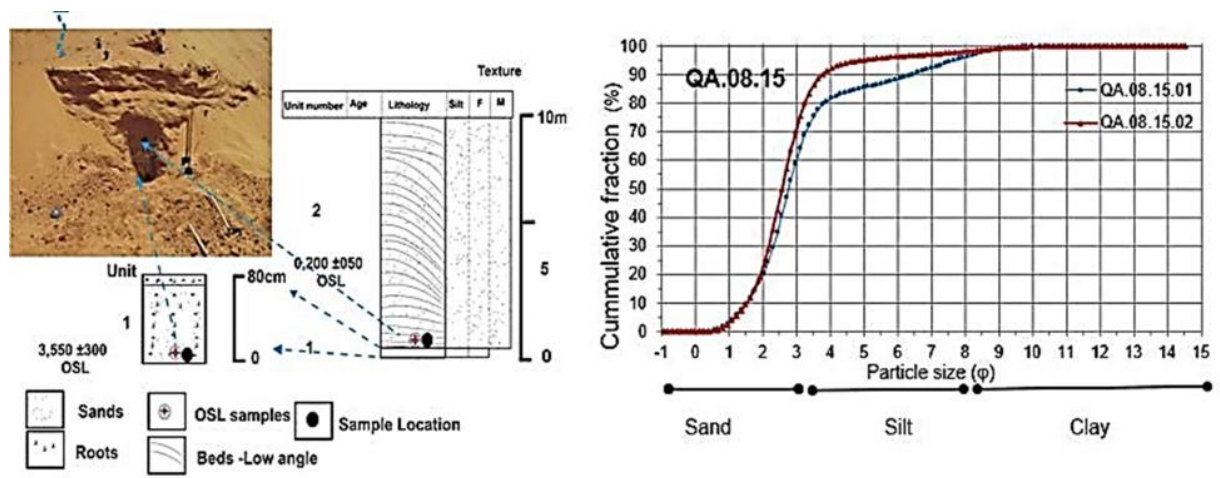

Figure 4: Nafud Al Qwarh section (QA.08.15) and cumulative percentage of its samples

The sand in the lower Nafud consists of orange (7.5 YR 6/6) fine sands with a small amount of silt. The upper surface in Unit 1 has a thin $(<8$ $\mathrm{mm}$ ) crust-like surface that has dried out; suggesting that sand accumulation stopped for a short a period. Unit 1 gives an age of mid Holocene $3.5 \mathrm{ka}$ (table 3). Unit 2 initially starts as low-angled beds that become steeper towards the top.

The particles are moderately-sorted fine to medium sands. There is evidence of roots and some specks of charcoal suggesting either naturally burning vegetation or some human activity. An OSL date from a depth 9 $\mathrm{m}$ from the top of sand dunes gives an age of 200-year age.

(Table. 3) OSL dates obtained from N. Qwarh section (QA.08.15) 


$\begin{array}{ccccccccc}\text { Sample } & \begin{array}{c}\text { Depth } \\ (\mathrm{m})\end{array} & \begin{array}{c}\text { De } \\ \left(\mu \mathrm{Gy} \mathrm{a} \mathrm{a}^{-1}\right)\end{array} & \begin{array}{c}\text { Dose } \\ (\mathrm{uGy} / \mathrm{ka})\end{array} & \begin{array}{c}\text { Age } \\ \mathrm{Ka}\end{array} & \begin{array}{c}\text { Alpha } \\ (\mathrm{uGy} / \mathrm{ka})\end{array} & \begin{array}{c}\text { Beta } \\ (\mathrm{uGy} / \mathrm{ka})\end{array} & \begin{array}{c}\text { Gamma Cosmic } \\ (\mathrm{uGy} / \mathrm{ka})(\mathrm{uGy} / \mathrm{ka})\end{array} \\ \text { QA.08.15 } & 10.80 & 9.57 \pm .66 & 2696 \pm 133 & 3.550 \pm 300 & 27 \pm 7 & 1677 \pm 125 & 925 \pm 42 & 66 \pm 3 \\ \text { QA.08.15 } & 10 & 0.48 \pm .12 & 2387 \pm 113 & 0.200 \pm 50 & 26 \pm 7 & 1454 \pm 107 & 840 \pm 38 & 67 \pm 3\end{array}$

\section{2- Nafud Uyun Al Jiwa QA.08.16}

This Nafud is located directly to the west of Uyun Al Jiwa village $\left(26^{\circ} 30^{\prime} 52^{\prime \prime} \mathrm{N}-43^{\circ} 36^{\prime} 60^{\prime \prime} \mathrm{E}\right)$. Extending for $10 \mathrm{~km}$ from Wadi Al Aswidah to the upper flanks of Nafud Buraydah. The Nafud form is a small linear dune with an overall east-southerly drift direction (average about $147^{\circ}$ ) (Fig. 3). This indicates that most of the sand formed parallel to the usual wind transport direction. The lower sample was collected at a depth of 40 m, (Fig. 5) and it consists of fine-grained sands, displaying moderatesorting.
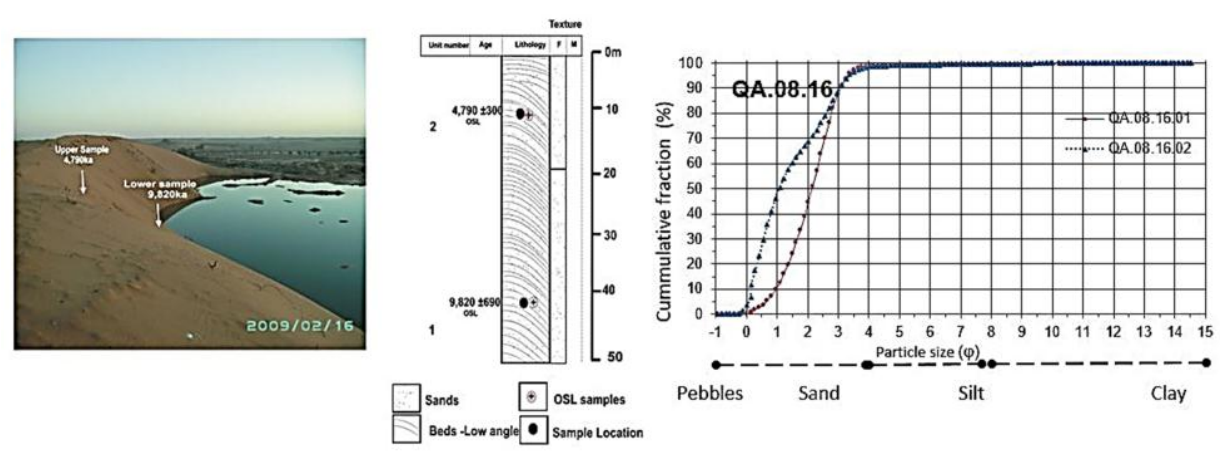

Figure 5: Nafud Uyun Al Jiwa section (QA.08.16) and cumulative percentage of its samples

There are fine laminae in this depth containing fine grained, indicate the different sorting of grains with a range of mineral types. An OSL dating from a height of $10 \mathrm{~m}$ from the base of the section gives an age 9.8 $\mathrm{ka}$ indicating an early Holocene age (table 4). An age of $4.7 \mathrm{ka}$ was obtained from a height of $40 \mathrm{~m}$ from the base of the section which is related to the middle Holocene; this indicates a rough rate of accumulation of sand in this linear dune of $30 \mathrm{~m}$ over $5 \mathrm{ka}$ which means about $60 \mathrm{~cm}$ per one hundred years. 
(Table. 4) OSL dates obtained from Uyun Al Jiwa section (QA.08.16)

\begin{tabular}{|c|c|c|c|c|c|c|c|c|}
\hline Sample & $\begin{array}{l}\text { Depth } \\
\text { (m) }\end{array}$ & $\begin{array}{c}\text { De } \\
\left(\mu \mathrm{Gy} \mathrm{a}^{-1}\right)\end{array}$ & $\begin{array}{c}\text { Dose } \\
\text { (uGy/ka) }\end{array}$ & $\begin{array}{l}\text { Age } \\
\mathrm{Ka}\end{array}$ & $\begin{array}{c}\text { Alpha } \\
(\mathrm{uGy} / \mathrm{ka})\end{array}$ & $\begin{array}{c}\text { Beta } \\
(\mathrm{uGy} / \mathrm{ka})\end{array}$ & $\begin{array}{c}\text { Gamma } \\
(\mathrm{uGy} / \mathrm{ka})\end{array}$ & $\begin{array}{c}\text { Cosmic } \\
(\mathrm{uGy} / \mathrm{ka})\end{array}$ \\
\hline QA.08.16.1 & 40 & $9.86 \pm .46$ & $1004 \pm 53$ & $9,820 \pm 690$ & $11 \pm 3$ & $635 \pm 50$ & $339 \pm 16$ & $20 \pm 1$ \\
\hline QA.08.16.2 & 10 & $8.44 \pm .35$ & $1763 \pm 81$ & $4,790 \pm 300$ & $23 \pm 6$ & $1042 \pm 76$ & $632 \pm 29$ & $67 \pm 3$ \\
\hline
\end{tabular}

The western belts of the linear dune system in Qassim Region have indicated a general southerly drift direction, which would suggest that most sand formed parallel to the usual wind transport direction from north-westerly winds. This would appear to agree with Holm (1961), whereby maps of the direction of the Aeolian sand movements over the Arabian Peninsula showed the sand dunes in central Saudi Arabia to appear in a circular arc with a NW direction.

Additionally, the dunes on the North Emirates coast were formed under NNW winds (Glennie, 1994), and the building of Nafud Al Jafurah in eastern Saudi Arabia was associated with NW to NNW winds (Edgell, 2006). OSL dating has shown different periods of sand accumulation ca. 99.5 ka to 200 years ago. The oldest sand age has been obtained from the lower parts of Nafud Buraydah and has indicated that these sands which have become cemented by $\mathrm{CaCO}_{3}$ are about $99.5 \mathrm{ka}$. This has occurred under the effects of rising water tables and strong shamal winds which have played a major role in the accumulation and development of these dunes.

An age obtained from the lower Nafud Uyun Al Jiwa is close to the age of Nafud Buraydah. This Nafud was deposited around 9.8 ka. These ages support the argument that indicates that Aeolian deposition persist as ineffective evidence for arid conditions in the Arabian Peninsula. For example, Stokes and Bray (2005) argued that the sand dune accumulation at Liwa in the United Arab Emirates occurred during wetter phases which were controlled by the sea level and precipitation that coincided with global climate variations. Goudie et al. (2000), in the Awafi linear $\left(25^{\circ} \mathrm{N}\right)$ sand dunes in Ras Al Khaimah (UAE), showed that dunes developed between $9.1 \mathrm{ka}-10.7 \mathrm{ka}$ and concluded that aridity could not be considered the critical factor of sand accumulation and may have accumulated as a 
response to sediment supply and vegetation destabilization by expanding humans during the late Pleistocene and the early Holocene.

In addition, in the Wahiba sands, aeolianite representing the Aeolian activity related to $10 \mathrm{ka}$ and $10.5 \mathrm{ka}$ (Juyal et al., 1998). The dune accumulation in southern Arabia corresponded with the northward movement of the monsoon winds (Neff et al., 2001 and Fleitmann et al., 2004). The migration of humans into inner Arabian Peninsula has been influenced by the monsoon moisture during the early Holocene (Parker., 2009).

Comparable evidence of dunes building in the early Holocene in Africa showed agreement with dunes building in the Arabian Peninsula; for example, the linear dunes in the interior of the central southern Kalahari Sahara were active during 11-13 ka (Thomas et al., 1998). The dunes building in the southern cape continued to accumulate during the Holocene, ca. $10.7 \mathrm{ka}$ (Bateman et al., 2004). In addition, it was similar to those observed in Kalahari, where the sand dune accumulation continued during ca.10 to $8 \mathrm{ka}$ (Telfer and Thomas, 2007 and Bateman et al., 2003).

In the mid Holocene, sand accumulation was found during ca. $4.7 \mathrm{ka}$, in the upper parts of linear dunes named the Nafud Uyun Al Jiwa. The ages obtained have agreed with the hypothesis that in the mid-Holocene, arid conditions prevailed in the Arabian Peninsula; and that the shamal winds played a major role in the sand deflection (Lezine et al., 1998). Results from high-pressure cells over northern Arabia (Edgell, 2006) also withdraw of the monsoon precipitation, that decreased gradually in response to changing northern hemisphere summer solar insolation; with decadal to multi-decadal variations in monsoon precipitation being linked to solar activity (Fleitmann et al., 2003, 2007; Parker et al., 2004, 2006).

The records relating to the Awafi Lake at Ras Al Khaimah (UAE) showed that Awafi filled with red sands and fine carbonate was blown into the lake around ca. $4.1 \mathrm{ka}$. This may have been related to more than factor, and weakened the influence of the IOM that retreated southwards, and human activity (Parker, et al., 2004, 2006). In addition, the sand 
dunes around Sabkhat Matti in southern Saudi Arabia have shown that sand accumulation was related to ca. $5.9 \mathrm{ka}$.

This evidence is consistent with the mid-Holocene, arid conditions in Africa, where most of the studies have interpreted sand building as equating to arid periods (Telfer \&Thomas., 2007). For instance, in Inner Mongolia Aeolian activity prevailed with a long-term oscillation trend towards arid conditions between 6.5-5.5 ka. The dunes migration and deflection in Umm Akhtar playa in southern Egypt was also around 6.7 ka. In addition, a sand-sheet in the Selima Sand Sea accumulated during a brief moist period in the Holocene between ca. 3-4 ka (Stokes et al., 1998); and upper linear dunes in Witpan Aeolian sand deposition continued to accumulate during ca 4.9 to $3.1 \mathrm{ka}$ (Telfer \&Thomas., 2007).

During late Holocene, around $3.5 \mathrm{ka}$, the sand sheet continued its developments in Nafud Al Qwarh. This would suggest evidence of weathering predictions which correspond with drier conditions from nearby areas via Wadi Aswidah. The evidence of roots and the presence of silt would suggest that the first stage of the sand accumulation was a result of stabilization by vegetative cover. According to Preusser et al (2005) with regards to the Khuwaymah sands in Oman, such Aeolian sand contained paleosol layers with fauna and roots and coincided with the end of the Holocene around ca.3.6. They assumed that this represented arid climatic conditions and the paleosol horizons and root implied moist conditions due to the special setting near the coastal area and slight increase of the water table.

The latter date of Nabkah on the wadi Rghwah developed around ca. $2.1 \mathrm{ka}$. The sand formation has usually been associated with wind deflection from the nearby Nafud Al Sirr under the effectiveness of the shamal winds. By the last 200 hundred years, the upper sand sheet at section (QA.08.15.02) within the Nafud Al Qwarh would suggest that these sands accumulated over a short time frame as a result of increased wind intensity and associated human activity.

The sand formation in the Rghwah Nabkah has coincided with peaking of Aeolian reworking from the Liwa area in the southern Arabia at ca 2.8 
ka. In addition, it coincided with linear dune formation in the Witpan area whereby their formation continued during the late Holocene ca $2.8 \mathrm{ka}$ to 500 years

In the Buraydah area the historical records have described the Buraydah area being around 100-200 years of age, with localized wadi flow and heavy rain during winter and a long, hot dusty season over consecutive years (Aldughairi, 2003). Comparable results were observed by (Telfer \& Thomas., 2007) in the upper dunes in the northern Witpan area where their accumulations have been sporadically active for much of the Holocene between ca. 840 to 150 years ago.

A red weathered deposits have been estimated as interglacial during MIS7ca. 221ka. The grain size distribution and red coating has suggested that they were derived from the adjacent Nafud. The red stain around the sand grains may have been weathered out from the sandstone bedrock of the Jillh Formation that contained Hematite; perhaps under the influence of increased moisture levels.

Schwertmann (1993) argued that the formation of Hematite required enough moisture with high temperatures to form. No correlation supported this period $(221 \mathrm{ka})$ in central Saudi or even in the south and east; except the period mentioned by archaeological observations by Petraglia et al., (2009) They cited that stone tools were found by Whalen et al., (1988) in the Dawadmi area which related to 200 to $204 \mathrm{ka}$; and during this time Acheulean hominines were present around lakes, and the environment was thought to be wet with a complement of plants and animals.

Additionally, Frumkin et al (2008) found evidence in the Black Desert on the north Arabian Desert in Jordan $\left(32^{\circ} \mathrm{N}\right)$ for moist episodes between 230 to $220 \mathrm{ka}$ due to the effect of Mediterranean cyclonic systems in the area; which received moisture from the warm Mediterranean Sea.

\section{3- Nafud Buraydah QA.08.05}

The dune field to the west of Buraydah city $\left(26^{\circ} 20^{\prime} 33^{\prime \prime} \mathrm{N}\right.$ $43^{\circ} 56^{\prime} 03^{\prime \prime} \mathrm{E}$ ), extends for $40 \mathrm{~km}$, from Wadi al Rumah in the south until it joins the Nafud Uyun Al Jiwa in the North (Fig. 3). The predominant 
dune morphology is linear, the axis drift is predominantly towards the south east and south west (direction rose $175^{\circ}$ and $210^{\circ}$ ) which suggests that dunes form in bidirectional winds, at present winds coming from north-westerly in summer (NW) but in winter winds come from the northeast.

The lowermost part of Nafud Buraydah (Fig. 6), comprises an aeolianite containing varying amounts of carbonate nodules and abundant rhizoliths running throughout the unit. Grain size analysis shows that this deposit is very fine sands (Fig. 6). The sands are indurated with increasing levels of cementation towards the top of unit 1B. The cementation pattern suggests that they formed in the capillary fringe above the groundwater table with rapid evaporation at the surface. The age of this deposit is $99.5 \mathrm{ka}$ (table 4.9), and falls into MIS stage $5 \mathrm{~d}$ according to Willoughby's (2007) definition. In this age should be note that the carbonate nodules and abundant rhizoliths running throughout the unit could be provide older age but the De estimates are still lie close to the dose saturation of quartz (Table 5). Overlying the aeolianite are loose Aeolian sands that are laminated with low angle bedding, at the base and the angle increase towards the top. The deposit is dominated by moderately sorted medium sands. An OSL age from the base of the section gives an age of $9.4 \mathrm{ka}$. This sample was taken just to the east of where $2 \mathrm{~B} \& 2 \mathrm{C}$ were sampled. This was because workmen had been removing sand from beneath where we sampled and it had slumped. Above the former deposits $2 \mathrm{~B}$ around at a depth of $20 \mathrm{~m}$ from the base of the section was sampled, it has a Holocene age, of $10.8 \mathrm{ka}$. An OSL age of $9.5 \mathrm{ka}$ from a height $40 \mathrm{~m}$. The ages from $20 \mathrm{~m}$ to $40 \mathrm{~m}$ suggest that there has been significant Aeolian activity in the early Holocene. The dune has accumulated about 20 metres of sand during 1,290 ka, which means $1.55 \mathrm{~m}$ per 100 years that suggests high rates of sand accumulation. 

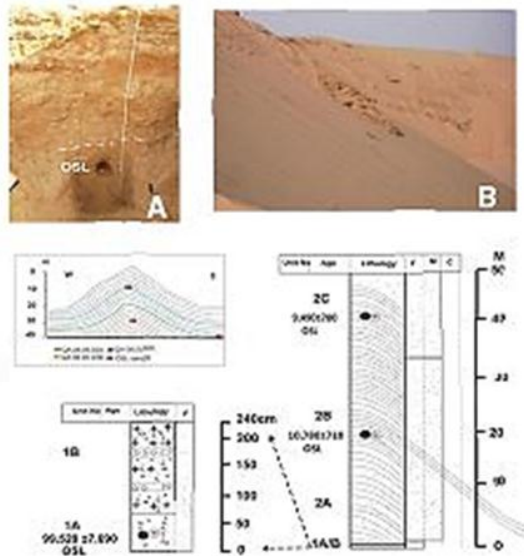

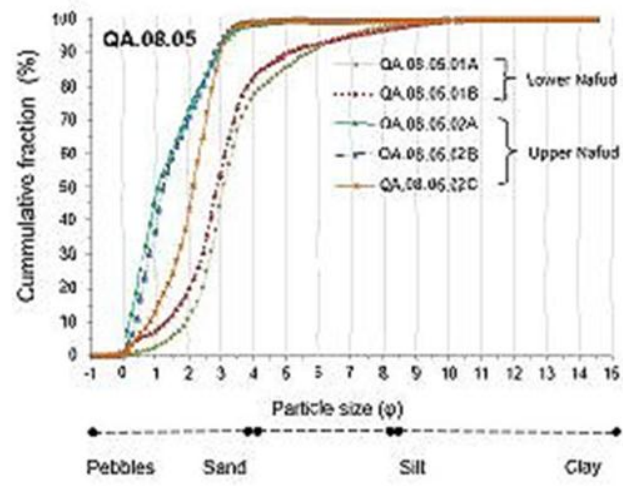

smon,

Figure 6: Nafud Buraydah section (QA.08.05) and cumulative percentage of its samples

The western belts of the linear dune system in the study area have indicated a general southerly drift direction, which would suggest that most sand formed parallel to the usual wind transport direction from north-westerly winds. This would appear to agree with Holm (1961), whereby maps of the direction of the Aeolian sand movements over the Arabian Peninsula showed the sand dunes in central Saudi Arabia to appear in a circular arc with a NW direction.

Additionally, the dunes on the North Emirates coast were formed under NNW winds (Glennie, 1994), and the building of Nafud Al Jafurah in eastern Saudi Arabia was associated with NW to NNW winds (Edgell, 2006). OSL dating has shown different periods of sand accumulation ca. $99.5 \mathrm{ka}$ to 200 years ago. The oldest sand age has been obtained from the lower parts of Nafud Buraydah and has indicated that these sands which have become cemented by $\mathrm{CaCO}_{3}$ are about $99.5 \mathrm{ka}$. This has occurred under the effects of rising water tables and strong shamal winds which 
have played a major role in the accumulation and development of these dunes.

(Table. 5) OSL dates obtained from Buraydah section (QA.08.05)

$\begin{array}{ccccccccc}\text { Sample } & \begin{array}{c}\text { Depth } \\ (\mathrm{m})\end{array} & \begin{array}{c}\text { De } \\ \left(\mu \mathrm{Gy} \mathrm{a}^{-1}\right)\end{array} & \begin{array}{c}\text { Dose } \\ (\mathrm{uGy} / \mathrm{ka})\end{array} & \begin{array}{c}\text { Age } \\ \text { Ka }\end{array} & \begin{array}{c}\text { Alpha } \\ (\mathrm{uGy} / \mathrm{ka})\end{array} & \begin{array}{c}\text { Beta } \\ (\mathrm{uGy} / \mathrm{ka})\end{array} & \begin{array}{c}\text { Gamma } \\ (\mathrm{uGy} / \mathrm{ka})(\mathrm{uGy} / \mathrm{ka})\end{array} \\ \text { QA.08.05.01A } & 53 & 157,47 \pm 9.18 & 1582 \pm 80 & 99,520 \pm 7,690 & 18 \pm 5 & 1011 \pm 76 & 534 \pm 25 & 19 \pm 1 \\ \text { QA.08.05.02A } & 51 & 8.79 \pm .39 & 936 \pm 49 & 9,390 \pm 650 & 9 \pm 2 & 590 \pm 47 & 305 \pm 14 & 32 \pm 2 \\ \text { QA.08.05.02B } & 30 & 9.526 \pm .377 & 884 \pm 46 & 10,780 \pm 710 & 10 \pm 2 & 555 \pm 44 & 298 \pm 14 & 22 \pm 1 \\ \text { QA.08.05.02C } & 10 & 10.15 \pm .66 & 1070 \pm 54 & 9,490 \pm 780 & 9 \pm 2 & 661 \pm 52 & 333 \pm 15 & 67 \pm 3\end{array}$

This aeolianite is the only one that has been found so far in the study area. It has displayed all the classical characteristics of aeolianite as described in McLaren (2007). The age of this aeolianite would appear to be close to the ages obtained by Preusser et al. (2002) for Aeolian dune formation in Al Jafr in Oman, indicating phases of dune activity occurrence around 120-100 ka. In addition, the age obtained was close to the sand accumulation in the Witpan area of South Africa $\left(\mathrm{ca} .26^{\circ} \mathrm{N}\right.$ ) which continued accumulating during MIS5c (ca.92 to 104ka) due to differing factors such as: less rain and lower temperatures; no rainfall reduction and higher temperatures; low soil moisture and greater sediment availability and greater frequency of sand transporting winds (Telfer \& Thomas, 2007)

In the MIS3 ca. 49 ka the sand dunes in the Dasmah within Nafud Al Thuwayrat, were active under the effect of shamal winds, with the water table availability which was an important control of sand accumulations. This date has been consistent with the argument put forward by Fleitmann et al. (2007), who suggested that this period $50 \mathrm{ka}$ was a hyper arid phase; and dune accumulation had thus been active in the Wahiba sands.

Moreover, there has been further evidence for increased sand dune building at Liwa sands, during ca 45; 51; 54 and 60 under the effect of shamal winds. Linear dunes in the Witpan area of South Africa also accumulated during ca. 57-52 ka (Telfer and Thomas, 2007). 
The date $49 \mathrm{ka}$ has not been in accordance with the findings of McLaren et al. (2008) and Al Juaidi (2003), who provided evidence of wetter events in the outwash plains that occurred at $54 \mathrm{ka}$ and $53.9 \mathrm{ka}$; which they argued were associated with phases of increased rainfall and/or decreased evaporation that prevailed in central Saudi Arabia. Again if the dunes and outwash fans formed around the same time this may indicate that either the dunes were not a good indicator of aridity and/or the wet events identified by McLaren et al (2008) and Al Juaidi (2003) were small-scale localised events.

In the early Holocene, around $11.3 \mathrm{ka}$, Nafud Dasmah within Nafud Al Thuwayrat, (section QA.08.08), showed high levels of roots and burrows and some carbonate development. This would suggest that such sand accumulation corresponded with a rise in the water table and a slightly wetter phase. In addition, sand deposits at Nafud Burydah showed indications that dunes were still active and the water table was an important control of sand stabilisation. The subsequent accumulation which coincided with lacustrine tufa developed in the interdunes areas. The units QA.08.05.02A to QA.08.05.02C, are both Holocene with estimated OSL ages of 9.5-10.5 ka respectively.

The vertical accumulation rate between Units QA.08.05.02B and QA.08.05.02C has been $15.5 \mathrm{~m} \mathrm{ka}^{-1}$ which would suggest extremely high levels of sand accumulation, with rates that are about five times faster than the linear dunes in Rub Al Khali (UAE) studied by Goudie et al., (2000). In this study, Holocene dunes from Awafi accumulated at a vertical rate of $3.3 \mathrm{~m} \mathrm{ka}^{-1}$ which they argued, "accumulated very rapidly $\sim 10,000$ years ago" (pg. 1001). This is very interesting as it implies a large sediment source and very high sediment transport rate from the Great Al Nafud to Nafud Buraydah.

An age obtained from the lower Nafud Uyun Al Jiwa is close to the age of Nafud Buraydah. This Nafud was deposited around $9.8 \mathrm{ka}$. These ages support the argument that indicates that Aeolian deposition persist as ineffective evidence for arid conditions in the Arabian Peninsula. For example, Stokes and Bray (2005) argued that the sand dune accumulation at Liwa in the United Arab Emirates occurred during wetter phases which 
were controlled by the sea level and precipitation that coincided with global climate variations. Goudie et al. (2000), in the Awafi linear $\left(25^{\circ} \mathrm{N}\right)$ sand dunes in Ras Al Khaimah (UAE), showed that dunes developed between $9.1 \mathrm{ka}-10.7 \mathrm{ka}$ and concluded that aridity could not be considered the critical factor of sand accumulation and may have accumulated as a response to sediment supply and vegetation destabilisation by expanding humans during the late Pleistocene and the early Holocene.

In addition, in the Wahiba sands, aeolianite representing the Aeolian activity related to $10 \mathrm{ka}$ and $10.5 \mathrm{ka}$ (Juyal et al., 1998). The dune accumulation in southern Arabia corresponded with the northward movement of the monsoon winds (Neff et al., 2001 and Fleitmann et al., 2004). The migration of humans into inner Arabian Peninsula has been influenced by the monsoon moisture during the early Holocene (Parker., 2009).

Comparable evidence of dunes building in the early Holocene in Africa showed agreement with dunes building in the Arabian Peninsula; for example, the linear dunes in the interior of the central southern Kalahari Sahara were active during 11-13 ka (Thomas et al., 1998). The dunes building in the southern cape continued to accumulate during the Holocene, ca. $10.7 \mathrm{ka}$ (Bateman et al., 2004). In addition, it was similar to those observed in Kalahari, where the sand dune accumulation continued during ca.10 to $8 \mathrm{ka}$ (Telfer and Thomas, 2007 and Bateman et al., 2003).

In the mid Holocene, Nabkah in the Wadi Ragwah (QA.08.06), deposited around $5.3 \mathrm{ka}$, which showed that they were formed under the influence of slight wadi activity which coincided with strong shamal winds (NW) across the wadi via Nafud Al Sirr. Similar sand accumulation was found during ca. $4.7 \mathrm{ka}$, in the upper parts of linear dunes named the Nafud Uyun Al Jiwa. The ages obtained have agreed with the hypothesis that in the mid-Holocene, arid conditions prevailed in the Arabian Peninsula; and that the shamal winds played a major role in the sand deflection (Lezine et al., 1998; Texier et al., 2000; McCorriston et al., 2002 and Staubwasser and Weiss, 2006). Results from highpressure cells over northern Arabia (Edgell, 2006) also withdraw of the monsoon precipitation, that decreased gradually in response to changing 
northern hemisphere summer solar insolation; with decadal to multidecadal variations in monsoon precipitation being linked to solar activity (Neff et al., 2001, Fleitmann et al., 2003, 2007; Parker et al., 2004, 2006).

The records relating to the Awafi Lake at Ras Al Khaimah (UAE) showed that Awafi filled with red sands and fine carbonate was blown into the lake around ca. $4.1 \mathrm{ka}$. This may have been related to more than factor, and weakened the influence of the IOM that retreated southwards, and human activity (Parker, et al., 2004, 2006). In addition, the sand dunes around Sabkhat Matti in southern Saudi Arabia have shown that sand accumulation was related to ca. $5.9 \mathrm{ka}$ (Goodall, 1995).

This evidence is consistent with the mid-Holocene, arid conditions in Africa, where most of the studies have interpreted sand building as equating to arid periods (Telfer \&Thomas., 2007). For instance, in Inner Mongolia Aeolian activity prevailed with a long-term oscillation trend towards arid conditions between 6.5-5.5 ka. The dunes migration and deflection in Umm Akhtar playa in southern Egypt was also around 6.7 ka. In addition, a sand-sheet in the Selima Sand Sea accumulated during a brief moist period in the Holocene between ca. 3-4 ka (Stokes et al., 1998); and upper linear dunes in Witpan Aeolian sand deposition continued to accumulate during ca 4.9 to $3.1 \mathrm{ka}$ (Telfer \&Thomas., 2007).

By the late Holocene, around $3.5 \mathrm{ka}$, the sand sheet continued its developments in Nafud Al Qwarh. This would suggest evidence of weathering predictions which correspond with drier conditions from nearby areas via Wadi Aswidah. The evidence of roots and the presence of silt would suggest that the first stage of the sand accumulation was a result of stabilisation by vegetative cover. According to Preusser et al (2005) with regards to the Khuwaymah sands in Oman, such Aeolian sand contained paleosol layers with fauna and roots and coincided with the end of the Holocene around ca.3.6. They assumed that this represented arid climatic conditions and the paleosol horizons and root implied moist conditions due to the special setting near the coastal area and slight increase of the water table. 
The latter date of Nabkah on the wadi Rghwah developed around ca. $2.1 \mathrm{ka}$. The sand formation has usually been associated with wind deflection from the nearby Nafud Al Sirr under the effectiveness of the shamal winds. By the last 200 hundred years, the upper sand sheet at section (QA.08.15.02) within the Nafud Al Qwarh would suggest that these sands accumulated over a short time frame as a result of increased wind intensity and associated human activity.

The sand formation in the Rghwah Nabkah has coincided with peaking of Aeolian reworking from the Liwa area in the southern Arabia at ca 2.8 ka. In addition, it coincided with linear dune formation in the Witpan area whereby their formation continued during the late Holocene ca $2.8 \mathrm{ka}$ to 500 years.

In the Buraydah area the historical records have described the Buraydah area being around 100-200 years of age, with localised wadi flow and heavy rain during winter and a long, hot dusty season over consecutive years (Aldughairi, 2003). Comparable results were observed by (Telfer $\&$ Thomas., 2007) in the upper dunes in the northern Witpan area where their accumulations have been sporadically active for much of the Holocene between ca. 840 to 150 years ago.

A red weathered deposit has been estimated as interglacial during MIS7ca. 221ka. The grain size distribution and red coating has suggested that they were derived from the adjacent Nafud. The red stain around the sand grains may have been weathered out from the sandstone bedrock of the Jillh Formation that contained Hematite; perhaps under the influence of increased moisture levels.

Schwertmann (1993) argued that the formation of Hematite required enough moisture with high temperatures to form. No correlation supported this period $(221 \mathrm{ka})$ in central Saudi or even in the south and east; except the period mentioned by archaeological observations by Petraglia et al., (2009) They cited that stone tools were found by Whalen et al., (1988) in the Dawadmi area which related to 200 to $204 \mathrm{ka}$; and during this time Acheulean hominines were present around lakes, and the 
environment was thought to be wet with a complement of plants and animals.

Additionally, Frumkin et al (2008) found evidence in the Black Desert on the north Arabian Desert in Jordan $\left(32^{\circ} \mathrm{N}\right)$ for moist episodes between 230 to $220 \mathrm{ka}$ due to the effect of Mediterranean cyclonic systems in the area; which received moisture from the warm Mediterranean Sea.

\section{4- Nafud al Maysariyah}

Nafud al Maysariyah is small sand dune field, lies in the western portion of Qassim region directly to southern banks of Wadi ar Rumah main channel, between longitudes $42^{\circ} 44^{\prime} 55^{\prime \prime}-42^{\circ} 55^{\prime} 10^{\prime \prime} \mathrm{E}$. and Latitudes $25^{\circ} 38^{`} 20^{\prime \prime}-25^{\circ} 41^{`} 25^{\prime \prime}$ N. (Fig. 7).

4-1- Results of Grain Size Analysis: Figure 8 and Table 6 show the grain size relationship between dune sands of Al Maysariyah field and the floodplain sediments of wadi ar Rumah, as well as percentage of sand classes, the output results are:

(Table 6) shows percentages of sand classes for recent, older dunes and the floodplain of Wadi ar Rumah.

$\begin{array}{lcccccc}\text { Dunes and } & \text { V. Coarse } & \text { Coarse } & \text { Medium } & \text { Fine } & \text { V. Fine } & \text { C. Silt } \\ \text { Floodplain } & -1 \phi & 0.0 \phi & 1.0 \phi & 2.0 \phi & 3.0 \phi & 4.0 \phi \\ \text { Recent } & 1.54 & 10.20 & 33.33 & 46.71 & 7.65 & 0.66 \\ \text { Older } & 0.00 & 2.03 & 55.83 & 33.96 & 7.06 & 1.18 \\ \text { Floodplain } & 1.32 & 10.43 & 32.05 & 45.68 & 9.12 & 1.50\end{array}$

- The percentage of very coarse plus coarse sands $(-1 \phi+0.0 \phi)$ in general decreases. But it relatively increases in the recent dunes $(11.74 \%)$ and in Wadi ar Rumah's floodplain (11.75\%), while it is only $2.03 \%$ in older dune sands.

- The percentage of medium plus fine sands $(1.0 \phi+2.0 \phi)$ extremely increases, so it is of importance to take into consideration that the sand dunes and the floodplain of Wadi ar Rumah are essentially formed from medium and fine sediments.

- The percentage of very fine sands plus coarse silt $(3.0 \phi+4.0 \phi)$ decreases with relatively increasing in the formation of Wadi ar Rumah's floodplain. 
(Table 7) shows the vertical variation in percentages of dune and floodplain sand classes.

\begin{tabular}{|c|c|c|c|c|c|c|c|c|}
\hline \multirow{2}{*}{\multicolumn{2}{|c|}{ Sample No. }} & \multirow{2}{*}{$\begin{array}{c}\text { Depth } \\
\mathrm{cm}\end{array}$} & V. coarse & Coarse & Medium & Fine & V. fine & C. silt \\
\hline & & & 2- mm & $1-\mathrm{mm}$ & $0.5 \mathrm{~mm}$ & $0.25 \mathrm{~mm}$ & $0.125 \mathrm{~mm}$ & $0.05 \mathrm{~mm}$ \\
\hline \multirow{3}{*}{ 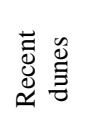 } & A-1 & 10 & 2.94 & 12.65 & 21.93 & 50.63 & 10.69 & 1.14 \\
\hline & A-2 & 50 & 0.72 & 5.91 & 37.16 & 50.94 & 5.32 & 0.31 \\
\hline & A-3 & 100 & 0.96 & 12.05 & 40.90 & 38.56 & 6.94 & 0.49 \\
\hline \multirow{3}{*}{ 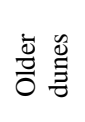 } & B-1 & 10 & 0.00 & 1.61 & 54.54 & 36.47 & 5.83 & 1.56 \\
\hline & B-2 & 50 & 0.00 & 2.46 & 57.48 & 31.94 & 7.04 & 1.15 \\
\hline & B-3 & 100 & 0.00 & 2.02 & 55.47 & 33.48 & 8.32 & 0.84 \\
\hline \multirow{2}{*}{ 寻 } & $\mathrm{C}-1$ & 10 & 1.68 & 10.82 & 29.21 & 47.02 & 10.33 & 1.13 \\
\hline & $\mathrm{C}-2$ & 50 & 0.95 & 10.04 & 34.88 & 44.34 & 7.90 & 1.86 \\
\hline
\end{tabular}

- Generally, the grain sizes of dune sands and the sediments of Wadi ar Rumah floodplain are quite closely and there is no considered differentiation between them. So that, sands forming the dunes may be was derived from the recent and old floodplains of Wadi ar Rumah.

- The older dune sands are coarser than the recent ones, where the percentage of coarse plus medium sands $(0.0 \phi+1.0 \phi)$ increases in older (lower) dunes and decreases in the recent (upper) dunes.

- The vertical variation of the percentage of coarse plus medium sands for the recent or upper dunes shows a downward increase.

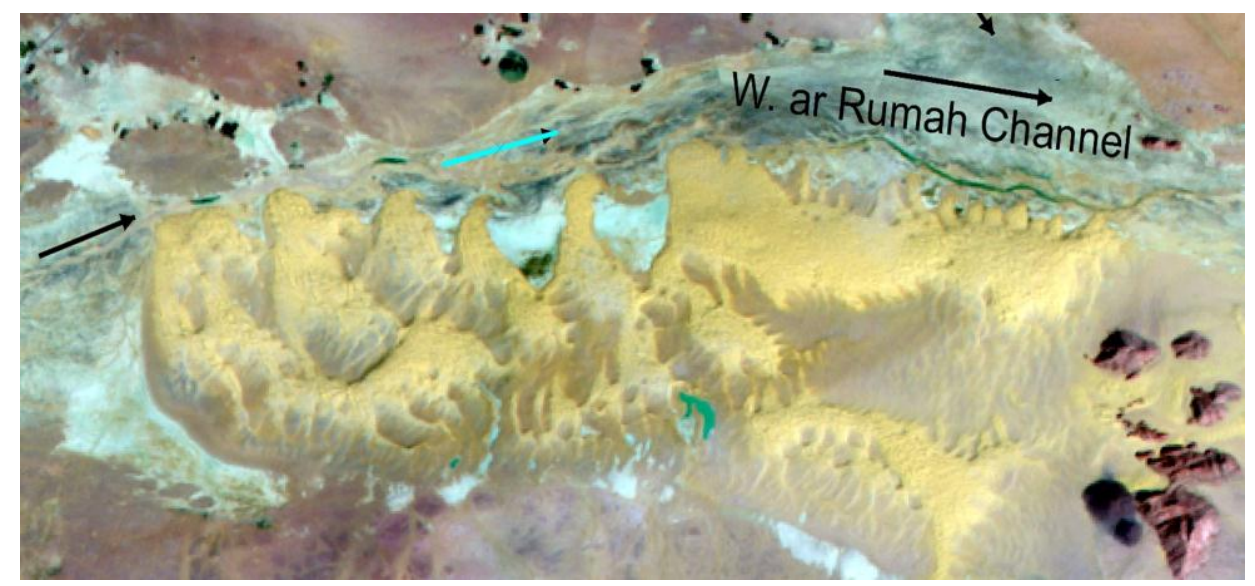

(Fig. 7) Al Maysariyah field dune directly to the south of wadi ar Rumah Channel 
(Fig. 8) Mean Grain Size Relationship Between Dune

Sands and W. ar Rumah floodplain

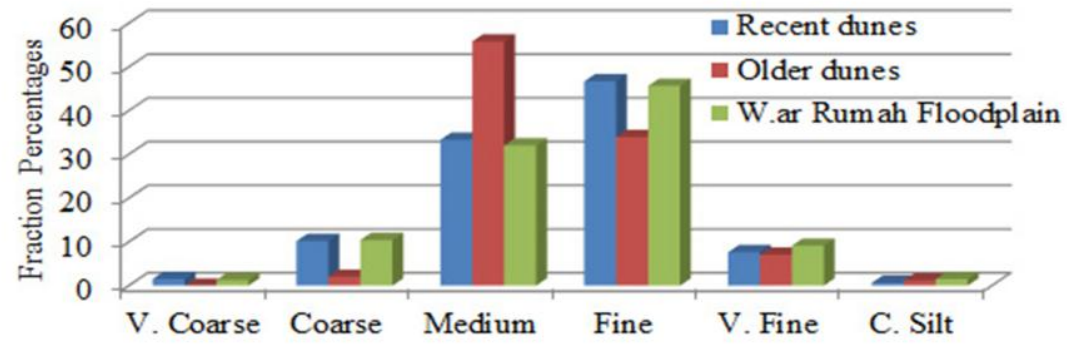

Now it is clear that there is a fining grain size cycle from the recent and old floodplains of Wadi ar Rumah to al Maysariyah dune field. The present study maintains that the floodplains of Wadi ar Rumah are the essential source of windblown sands and sand dunes. Owing to prevailing winds, the sand transport is accompanied with and southward shifting from the floodplains to the dunes. So, it is reasonable that the dune sands are more sorted than that of the floodplain once.

The results of mechanical analysis and the calculated grain size statistical parameters of both lower and upper dunes are used in the differentiation between them. These data are given in Table 8 and shown in Fig. 9.

Table 8: results of grain size statistical parameters of the lower and the upper dune sands and the sediments of Wadi ar Rumah floodplain.

\begin{tabular}{ccccccccccccc} 
Sample & Depth & \multicolumn{4}{c}{ Percentiles of Phi for Equations } & \multicolumn{4}{c}{ Statistical Parameters } \\
No. & cm & $\Phi 5$ & $\Phi 16$ & $\Phi 25$ & $\Phi 50$ & $\Phi 75$ & $\Phi 84$ & $\Phi 95$ & Mz & 6 I & SKI & KG \\
A-1 & 10 & -0.75 & 0.00 & 0.25 & 1.33 & 1.80 & 2.00 & 2.75 & 1.11 & 1.03 & -0.26 & 0.93 \\
A-2 & 50 & -0.20 & 0.50 & 0.75 & 1.50 & 1.60 & 1.80 & 2.10 & 1.30 & 0.62 & -1.00 & 1.26 \\
A-3 & 100 & -0.60 & 0.00 & 0.20 & 0.85 & 1.35 & 1.75 & 2.40 & 0.87 & 0.89 & 0.03 & 1.07
\end{tabular}




$\begin{array}{lcccccccccccc}\text { B-1 } & 10 & 0.20 & 0.60 & 0.75 & 1.00 & 1.40 & 1.60 & 2.50 & 1.07 & 0.60 & 0.25 & 1.45 \\ \text { B-2 } & 50 & 0.10 & 0.50 & 0.70 & 0.95 & 1.20 & 1.60 & 2.35 & 1.02 & 0.62 & 0.21 & 0.62 \\ \text { B-3 } & 100 & 0.10 & 0.50 & 0.65 & 0.95 & 1.33 & 1.65 & 2.40 & 1.02 & 0.64 & 0.24 & 1.39 \\ \text { C-1 } & 10 & -0.75 & 0.20 & 0.60 & 1.20 & 1.85 & 2.00 & 2.70 & 1.13 & 0.98 & -0.14 & 1.13 \\ \text { C-2 } & 50 & -0.50 & 0.20 & 0.50 & 1.15 & 1.55 & 1.85 & 2.65 & 1.07 & 0.89 & -0.10 & 1.23\end{array}$

Table 8 and Fig. 9 show that the sands of recent dunes (upper dunes) are finer, less sorted, slightly negative (fine) skewed, and have lower kurtosis values. This is in agreement with many studies (Anan, 1969; Ahlbrandt, 1979; Maxwell, 1982, and Embabi and Ashor, 1985). These studies were pointed out that the lower samples of dune sands were slightly coarser than the upper samples.

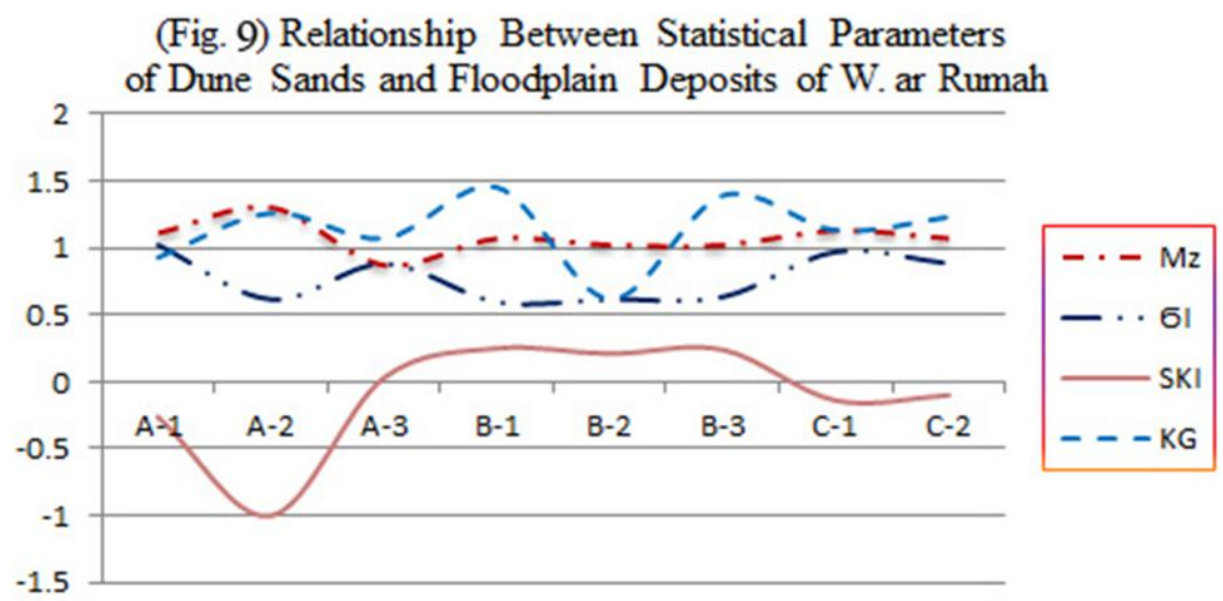

action most time of the year. So that, the coarse grains concentrate at the top of dunes and also near them foots.

\section{4-2- RESLTS OF GEOCHEMICAL ANALYSIS}

Geochemical analysis was carried out for all collected samples of al Maysariyah sand dunes and Wadi ar Rumah's floodplain (Table 9).

Normally, the $\mathrm{pH}$ level in most dune sands and soils varies from 3 to 9 . Various categories of soil $\mathrm{pH}$ may be arbitrarily described as follows: Strongly acid $(\mathrm{pH}<5.0)$, moderately to slightly acid $(5.0-6.5)$, neutral (6.5- 7.5), moderately alkaline (7.5- 8.5) and strongly alkaline (> 8.5). Accordingly, all samples of the present study were moderately alkaline, where the $\mathrm{pH}$ value varies from 7.69 to 8.20 with an average of 7.996 . Hazelton and Murphy (2007) pointed out that soils of drier areas are generally alkaline i.e. about $\mathrm{pH} 7.0$ as a result of the presence of calcium carbonate (CaCO3). The older (lower) dunes and the floodplain of Wadi ar Rumah are more alkaline than the recent (upper) dunes (Table 9). 
Electrical conductivity (EC- ds $/ \mathrm{m}$ ) values range from 0.30 to $0.58 \mathrm{ds} / \mathrm{m}$ with a general average of 0.41 , while the total dissolved salts (TDS/ppm) values range from 192.0 to $371.2 \mathrm{ppm}$, with an average of $262.4 \mathrm{ppm}$. It is observed that the EC and TDS values tend to increase in the recent (upper) sand dunes and decrease with depth in both the older (lower) sand dunes and floodplain of Wadi ar Rumah. In the other words, however the EC and TDS values have the same trend, the EC is used to estimate the total salt contents of dune sands (Brady and Weil, 2002; Carter, 2002; Hamza and Anderson, 2005).

Table 9: Results of Geochemical Analysis of al Maysariyah Sand Dunes and Wadi ar Rumah Floodplain

Chemical character Recent dunes Older dunes Floodplain average $\begin{array}{llllllll}\text { A1 } & \text { A2 } & \text { A3 } & \text { B1 } & \text { B2 } & \text { B3 } & \text { C1 } & \text { C2 }\end{array}$

\begin{tabular}{|c|c|c|c|c|c|c|c|c|c|c|}
\hline pH & & 7.74 & 7.96 & 7.98 & 8.08 & 8.10 & 8.20 & 8.01 & 8.17 & 7.9 \\
\hline $\mathrm{EC}(\mathrm{ds} / \mathrm{m})$ & & 0.37 & 0.58 & 0.32 & 0.47 & 0.47 & 0.31 & 0.46 & 0.30 & .41 \\
\hline $\mathrm{DS}$ & & 37 & 371 & 205 & 301 & 301 & 198 & 294 & 192 & 262 \\
\hline & & 0.91 & 0.92 & 0.88 & 1.17 & 1.0 & 0.9 & 1.04 & 0.96 & $0.9^{\prime}$ \\
\hline & & 4.0 & 5.1 & 2.6 & 3.3 & 3.2 & 2.3 & 3.6 & 2.4 & 0.3 \\
\hline sium & & 0.8 & 0.9 & 0.3 & 0.3 & 0.4 & 0.7 & 1.03 & 1.0 & 0.6 \\
\hline arbonate & & 2.1 & 2.0 & 2.2 & 2.4 & 2.3 & 2.4 & 2.0 & 2.1 & 1 \\
\hline hhloride & & 1.3 & 1.3 & 0.95 & 1.12 & 1.2 & 0.8 & 1.1 & 0.93 & 1.0 \\
\hline ron & & 0.2 & 0.48 & 0.44 & 0.30 & 0.24 & 0.24 & 0.12 & 0.12 & 0.2 \\
\hline & ⿷ & 0.32 & 0.58 & 0.5 & 0.28 & 0.32 & 0.26 & 0.29 & 0.29 & 0.3 \\
\hline & दे & 0.72 & 0.96 & 0.63 & 0.77 & 0.81 & 0.82 & 0.82 & 0.82 & \\
\hline & & 0.09 & 0.07 & 0.08 & 0.07 & 0.07 & 0.05 & 0.06 & 0.06 & \\
\hline
\end{tabular}

The available cations: sodium $(\mathrm{Na})$, calcium $(\mathrm{Ca})$ and magnesium $(\mathrm{Mg})$ have general averages of $0.97,3.31$ and $0.681 \mathrm{meq} / \mathrm{L}$ respectively. These elements can be held in the dune sands and not lost through leaching. The lower values of these elements reflect the lowering percentages of clay minerals in the studied samples.

The carbonate and bicarbonate values tend to distribute from upper to bottom sands in narrow range, and have a general average of 2.19 $1 \mathrm{meq} / \mathrm{L}$. Inorganic carbonate, either as calcium or magnesium carbonate or mixture of both, occur in dune sands as a result of weathering, or is inherited from the parent material. Chloride has the same distribution with a general average of $1.091 \mathrm{meq} / \mathrm{L}$. Although, it is found widely distributed in nature in the form of salts of $\mathrm{Na}, \mathrm{Ca}$, and $\mathrm{K}$, the lowest 
value of chloride in dune sands is attributed to the lesser amount of dune organic matter.

The chemical analysis of the dunes under investigation was indicated that the concentration of micronutrient metals (iron, mangnesium, zinc, and copper) decreased significantly with decrease in finer fraction (very fine sand and coarse silt) because these fractions are helpful to improve dune structure and aeration which are favorable conditions for increasing its availability. The available $\mathrm{Fe}$ and $\mathrm{Mg}$ contents in dune sands and the floodplain of Wadi ar Rumah ranged in general from 0.12 to 0.48 and from 0.24 to $0.58 \mathrm{ppm}$, with the main values of 0.27 and $0.35 \mathrm{ppm}$ respectively, while $\mathrm{Zn}$ and $\mathrm{Cu}$ ranged from 0.63 to 0.96 and from 0.05 to $0.09 \mathrm{ppm}$, with the mean values of 0.78 and $0.07 \mathrm{ppm}$ respectively. Dune sands and floodplain sediments have a similar range of $\mathrm{Fe}, \mathrm{Mg}, \mathrm{Zn}$, and $\mathrm{Cu}$ values, which probably reflect their identical source.

\section{4-3- INTERNAL STRUCTURE OF AL MAYSARIYAH DUNES}

Bagnold (1971) recognized that sand dunes are essentially composed of accretion and avalanche deposits. These two types of deposits can easily be observed and have been described by many authors (Hunter, 1977; Anderson, 1988; Embabi and Ashour, 1993; Bristow, Bailey and Lancaster, 2000; and Wigges, 2001)

Internal structure of dunes may be known from the natural exposures of the interiors of the dune or by excavating it. Five cuts were made, two in the south western side (lee-ward side) of the old dome-shaped dune, and the other three cuts in one of the recent barchans, one in the windward side near the foot, the second in the lee-ward side near the crest, and the later in the barchan horn as side trench.

\section{4-3-1- Internal structure of the old dome-shaped dune.}

The stratification of windblown sand at the south western side (leeward side) of a dome-shaped dune is clearly observed and involves four types of lamina and bounding surfaces between sets of lamina. It was observed that most of bounding surfaces are nearly straight and showed apparent dips ranges between $2^{\circ}-30^{\circ}$ reflecting varies condition during the deposition (Fig. 10). 


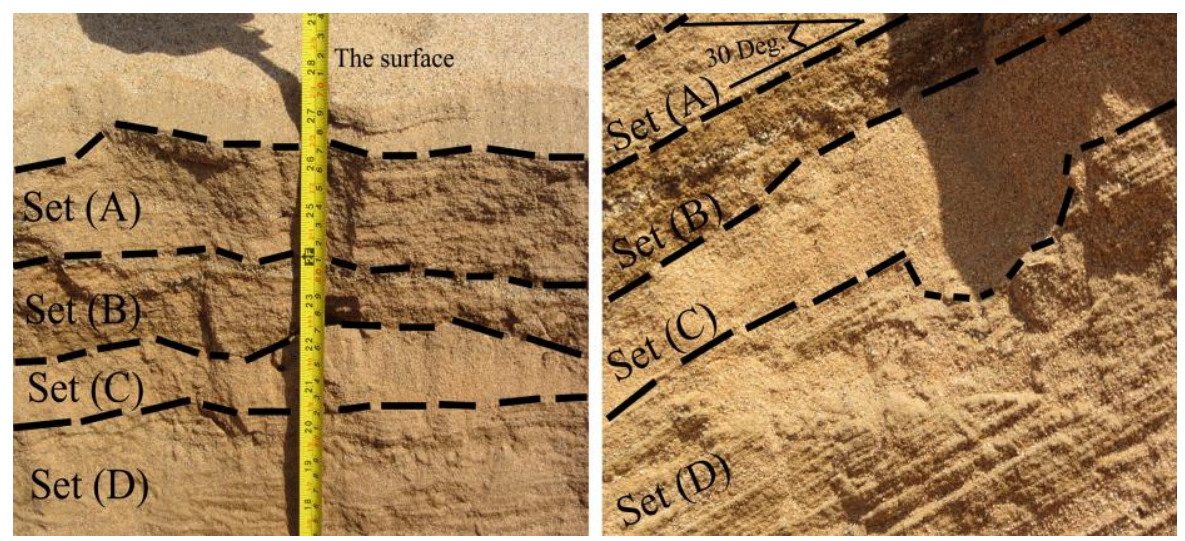

Figure 10: Internal structure characteristics of old dome-shaped dune, Nafud al Maysariyah
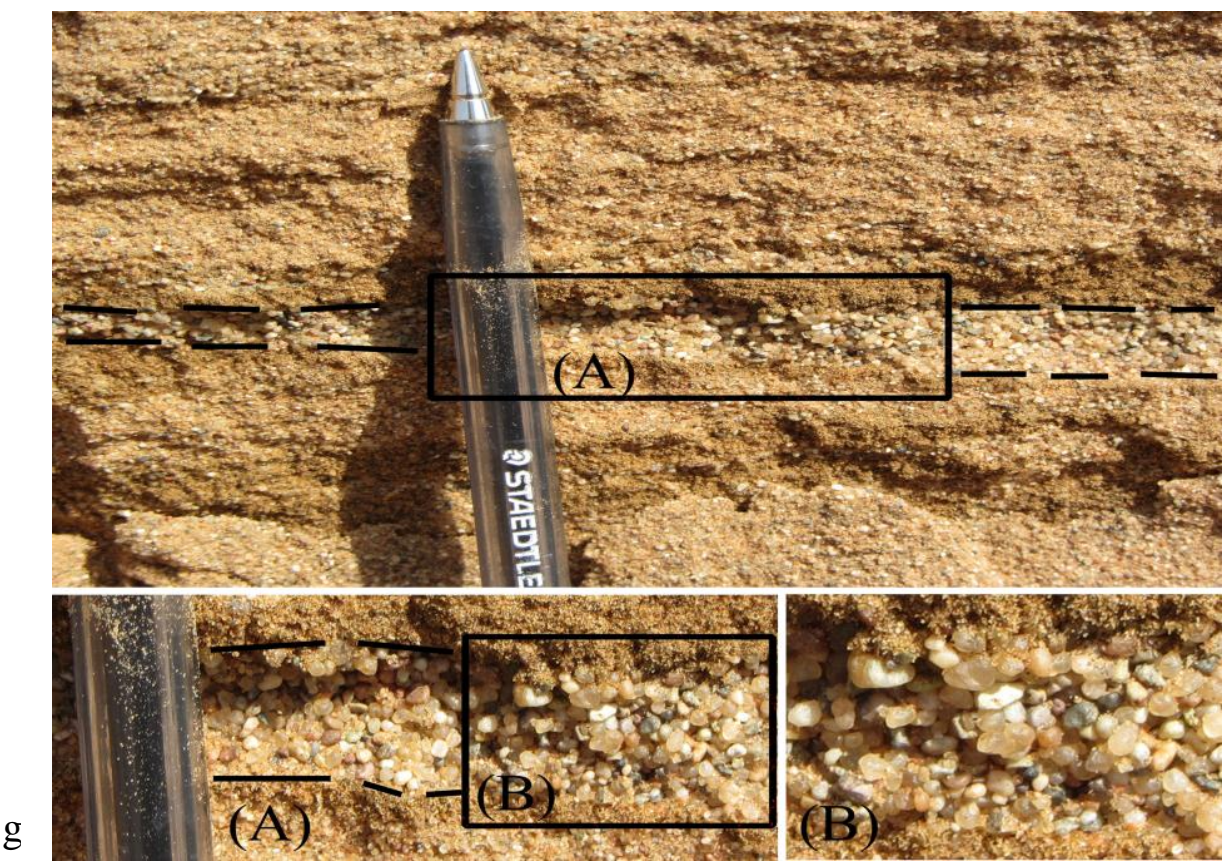

g Figure 11: show coarse grain-rich lamina, probably represent an

ancient dune surfaces

o

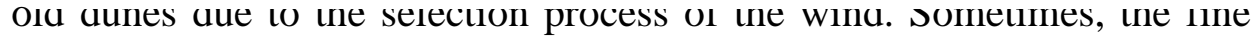
sediments can be easily carried and transported but the coarse ones are difficult to be removed by wind carrying. 


\section{4-3-2- Internal structure of the recent barchans}

It is observed that the windward side lamina and those near the foot of barchans are composed of convex lamina of sand as buried ripples, with wave length is about $45 \mathrm{~cm}$ (Fig. 12-A), indicating that were deposited directly from the creep and saltation loads of the wind. The individual laminae are rather thin and ranges between 0.2- $0.6 \mathrm{~mm}$ thick. The planertabular type of laminae is not common.

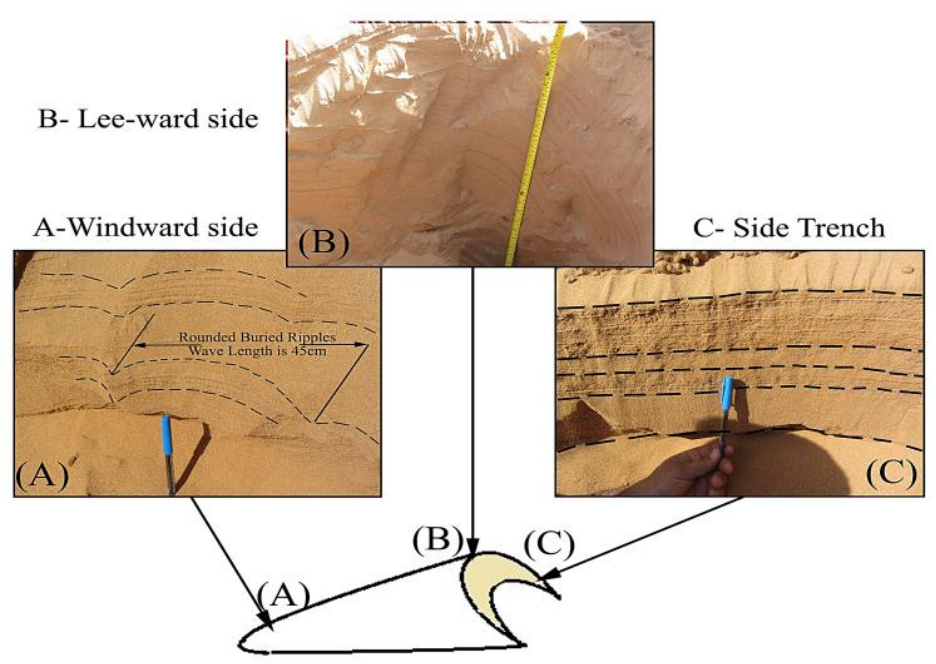

Figure 12: Show internal structure characteristics of

] barchan dune as a common shape in Nafud al Maysariyah nsist of cro: pes and are steeper than those of the windward side, probably due to avalanche deposits. Most surfaces bounding sets of cross-strata dipped from $12^{\circ}$ $33^{\circ}$ to lee-side, and most lamina within them are dipping somewhat more and varies between $18^{\circ}-35^{\circ}$ (dips less than $18^{\circ}$ are not common). The individual laminae are rather thick, about 2- $5 \mathrm{~cm}$. A series of deformational structures such as irregularity of bedding, slump folds and fractures are observed and are probably formed as a result of local slumps on the avalanche side.

A cut in barchan horn (side trench) shows a stratification pattern, which consists of nearly flat surfaces bounding planer-tabular laminae sets. Lamina within each set are horizontally bedding and are rather thin (Fig. 12-C).

The most important feature is the coarse grains are characterized by sub-rounded to completely rounded, such phenomenon has been 
attributed to the effect of running water transportation. Therefore, the sand forming the dunes is probably derived by wind essentially from the old and recent floodplains of Wadi ar Rumah and also from the other network channels in Qassim region.

\section{4-4- SUMMARY AND CONCLUSION}

In the study area, two dune patterns of different extension, type and age can be observed. The upper dune pattern is recent, while the lower is older. The two dune patterns represent two distinct periods of dune formation. In some locations, a grassy surface separates the two dune patterns.

At southern portions of Nafud al Maysariyah, the barchanoid dunes tend to modify to series of isolated barchans. Such modification occurs with the direction of prevailing wind. This may be indication to the instability of barchanoid dunes because recently wind velocities are not strong enough to maintain them.

On light of sand transport from Wadi ar Rumah's floodplain to Nafud al Maysariyah, by wind action, it is found that the variation of percentage of coarse plus medium sands in al Maysariyah dune field follows quite closely those ones that are found in the floodplain. There is a fining grain size cycle from the floodplain to dune field, whereas the sorting also improves. Such relationship maintains that the sediments of Wadi ar Rumah floodplains and other network channels in Qassim region is probably significant source of wind-blown sands?

Grain size parameters are used to differentiate between the recent and the old dune sands as well as the sediments of Wadi ar Rumah floodplain. The results indicate that the recent dune sands are finer, more sorted, slightly positive skewed and have lower kurtosis values than the old dune sands, and probably indicating the ancient wind was stronger than the recent wind.

Internal structure of a dome-shaped dune (old dune) and barchans dune (recent dune) is clearly observed due to five cuts were carried out, the stratification of wind-blown sand involves four types of laminae of different thickness and dips, and bounding surfaces between sets of laminae. Most of bounding surfaces in both two pattern dunes are straight and show apparent dips almost entirely towards lee-ward side. Lee-ward side laminae of barchans dune are steeper thicker than both windward and side trench laminae. A series of deformational structures are observed and probably formed as a result of local slumps on the avalanche side. 


$$
-\varepsilon \cdot 0_{-}
$$




\section{REFERENCES}

Ahlbrandt, T.S. (1979) Texture parameters of Aeolian Deposits. US Geological Survey Professional Paper, 1052: 21-51.

Al Dughairi, A., 2003: Geomorphologic Al watah in Saudi Arabia.

Master's Thesis, King Saud University, Riyadh Saudi Arabia.

Anan, P.S. (1969) Grain Size Parameters of the Beach Dune Sands, Northeast Mass. and New Hampshire Coasts- In: Coastal Environments. Univ. Mass., 266-280.

Anderson, R.S. (1988) The Pattern of Grain fall Deposition in the Lee of Aeolian Dunes. Sedimentology, 35 (2):175-188.

Anderson, R.S. (1990) Eolian Ripples as Examples of Self-organization in Geomorphological Systems. Earth Science Reviews, 29: 77-96.

Bagnold, R.A. (1941) The Physics of Blown Sand and Desert Dunes. Chapman and Hall, London. 265.

Boulton, J.W. (1997) Quantifying the Morphology of Aeolian Impact Ripples Formed in a Natural Dune Setting, University of Guelph, Guelph, Ontario Canada, 122.

Brady, N.C. and Weil, R.R. (2002) The Nature and Properties of Soils. $13^{\text {th }}$ ed. Pearson Education, Inc, New Jersey.

Bristow, C.S., Bailey, S.D. and Lancaster, N. (2000) Sedimentary Structure of Linear Sand Dunes. Nature, 406: 56-59.

Carter, M.R. (2002) Soil Quality for Sustainable Land Management: Organic Matter and Aggregation Interactions that Maintain Soil Functions. Agronomy Journal 94: 38-47.

Cole, J.C. (1985b) Reconnaissance Geology of the Uqlat as Suqur Quadrangle, Sheet 25/42A, Kingdom of Saudi Arabia: Saudi Arabian Deputy Ministry for Mineral Resources Open-file Report USGS-of05-14, 95. Scale 1: 100000.

Cole, J.C. (1985c) Reconnaissance Geology of the al Abanat Quadrangle, Sheet 25/42B, Kingdom of Saudi Arabia: Saudi Arabian Deputy Ministry for Mineral Resources Open-file Report USGS-of-05-17, 66. Scale 1: 100000.

Cole, J.C. (1986) Geology of Aban al Ahmar Quadrangle, Sheet 25F, Kingdom of Saudi Arabia: Saudi Arabian Deputy Ministry for Mineral Resources Open-file Report USGS-of-04-9, 85. Scale 1: 250000.

Edgell, H., 2006: Arabian desert nature, origin and evolution. Springer, Netherlands.

Edgell, H., 2006: Arabian desert nature, origin and evolution. Springer, Netherlands. 
Embabi, N.S. (1982) Barchans of the Kharga Depression.In:F. El-Baz and T. A. Maxwell (Eds.) Desert Landforms of Egypt: A basis for Comparison with Mars. NASA, Washington D.C., 141-156.

Embabi, N.S. and Ashour, M.M. (1993) Barchan Dunes in Qatar. Journal of Arid Environments 25; 49-69.

Fleitmann, D., Burns, S., Mangini, A., Mudelsee, M., Kramers, J., Villa, L., Neff, H., Al Subbary, A., Buettner, A., Hippler, D. and Matter, A., 2006: Holocene ITCZ and Indian monsoon dynamics recorded in stalagmites from Oman and Yemen (Socatra). Quaternary Science Reviews, Vol.26, p170-188.

Fleitmann, D., Butns, S., Mudelsee, M., Neff, U., Mangini, A., Matter, A., 2003: Palaeoclimatic interpretation of high-resolution oxygen isotope profiles derived from annually laminated speleothems from southern Oman. Quaternary Science Reviews. Vol 23, p.935-945.

Fleitmann, D., Matter, A., Pint, J., Al Ahanti, M. 2004: The Speleothem record of climate change in Saudi Arabia. Saudi Geological survey. Riyadh.

Folk, R.L. and Ward, W.C. (1957) Brazos River Bar: A study in the Significance of Grain Size Parameters, Jour. Sed. Petr. 27, 3-27.

Frumkin, A., Miryah, B., Vaks, A., 2008: Paleoenvironment of Jawa basalt plateau, Jordan, inferred from calcite spekeothems from a lava tube. Science Direct. Vol 70, p358-367.

Glennie, K., 1995. The desert southeast Arabia: A product of Quaternary climatic change. Geology of Quatern Glennie, 1994ary Desert Margins, Balkem. Rotterdm; 279-291.

Goudie, A., Golis, A., Stokes, S., Parker, A., White, K. and Al Farrajs, A., 2000: Latest Pleistocene and Holocene dune construction at the North eastern edge of the Rub al Khali, United Arab Emirates. International Association of sedimentolgists, Vol.47, p1001-1021.

Hamza, M.A. and Anderson, W.K. (2005) Soil Compaction in Cropping Systems. A review of the Nature, Causes and Possible Solutions. Soil and Tillage Research 82/2: 121-145.

Hazelton, P., Murphy, B. (2007) Interpreting Soil Test Results. NSW Department of Natural Resources, CSIRO.

Hunter, R.E. (1977) Basic Types of Stratification in Small Eolian Dunes. Sedimentology, 24: 361-388. 
Juyal, N., Singhvi, A. and Glennie, K., 1998: Chronology and palaeoenvieonmental significance of Quaternary desert sediment in southeastern Arabia. Geology of Quaternary Desert Margins, Balkem. Rotterdm; 315-325.

Lezine, Anne-Marie., Salieg, J., Inizan, M., 1998: Holocen Lake from Ramlate as Sab Atayn Yemen lllustrate the impacte of Monsoon Activity in Southern Arabia. Quaternary research. Paris, Franc. Vol .50. p290-299.

Maxwell, T., and Haynes, C. (2001) Sand sheet Dynamic and Quaternary Landscape Evolution of the Selima Sand Sheet, Southern Egypt. Quaternary Science Reviews, 20: 1623-1647.

Neff U, Burns SJ, Mangini A, Mudelsee M, Fleitmann D, Matter A. 2001:

Strong coherence between solar variability and the monsoon in Oman between 9 and 6 kyr ago. Nature 411: 290-293.

Neff U, Burns SJ, Mangini A, Mudelsee M, Fleitmann D, Matter A. 2001:

Strong coherence between solar variability and the monsoon in Oman between 9 and 6 kyr ago. Nature 411: 290-293.

Parker, A., 2009: Pleistocene climate change in Arabia: Developing a framework for Hominin dispersal over the Last 350ka. Springer Science, p 39-49.

Parker, A., 2009: Pleistocene climate change in Arabia: Developing a framework for Hominin dispersal over the Last 350ka. Springer Science, p 39-49.

Parker, A., Goudie, A., Stokes, S., White, K., Hodson, M., Manning, M. and Kennet, D., 2006: A record of Holocene climate change from lake geochemical analyses in south-eastern Arabia. Quaternary Research, Vol.66, 465-476

Parker, A., Preston, G., Walkington, H. and Hodson, M., 2006:

Developing a framework of Holocene climatic change and landscape archaeology for the lower Gulf region, south-eastern Arabia. Blackwell Publishing, Vol.17, $125-130$.

Parsons, A.J. and Abrahams, A.D. (2009) Geomorphology of Desert Environments, Second Edi. London.

Petraglia, D., Drake, N., Alsharekh, A. 2009. Acheulean Landscapes and large cutting tools assemblages in the Arabian Peninsula. Springer Science, p103-116. 
Preusser, F., Radies, D., Driehorst, F. and Matter, A. 2005. Late Quaternary history of the coastal Wahiba Sands, Sultanate of Oman.

Stokes, S and Horrocks, J., 1998: A reconnaissance survey of the linear dunes and loess plains of north-western Nigeria: Granulometry and geochronology. Geology of Quaternary Desert Margins, Balkem. Rotterdm; 165-174.

Stokes, S., Bray, H., 2005: Late Pleistocene aelian history of the Liwa region, Arabian Peninsula Geological Society of America. Vol 117, p 1466-1480.

Stuckless, J.S., Hedge, C.E., Wenner, D.B., and Nkomo, I.T. (1984) Isotopic Studies of Postorogenic Granites from the Northeastern Arabian Shield, Kingdom of Saudi Arabia: Saudi Arabian Deputy Ministry for Mineral Resources Open-file Report USGS-of-04: 42,40 .

Telfer, M. W. \& Thomas, D. S. G. 2007: Late Quaternary linear dune accumulation and chronostratigraphic of the southwestern Kalahari: Implications for Aeolian paleoclimate reconstructions and predictions of future dynamics. Quaternary Science Reviews 26, 2617-2630.

Teller, J., Glennie, K., Lancaster, N. and Singhvi, A., 2000: Calcareous dunes of the United Arab Emirates and Noah's Flood: the postglacial reflooding of the Persian Arabian Gulf. Quaternary International Vol.68, 297-308.

Thomas, D., Connor, P. and Stokes, S., 1998: Late Quaternary aridity in the south-western Kalahari Desert: New contribution from optically stimulated luminescence OSL dating of Aeolian deposits, northern Cape Province, South Africa. Geology of Quaternary Desert Margins, Balkem. Rotterdm; 209-224.

Waldmann, N., Torfstein, A., Stein, M., 2010: Northward intrusions of low and mid latitude storms across the Sahara Arabian belt during past interglacial. Geological Society of America, Vol 6 p 567-570.

Whitney, J.W. (1983) Erosion History and Surficial Geology of Wester Saudi Arabia: Saudi Arabian Deputy Ministry for Mineral Resources Technical Report USGS-TR-04-1, 90.

Wigges, G.F.S. (2001) Desert Dune Processes and Dynamics Progress in Physical Geography, 25 (1): 53-79. 